\title{
Oxidant Injury of Lung Parenchymal Cells
}

\author{
William J. Martin II, James E. Gadek, Gary W. Hunninghake, and \\ Ronald G. Crystal, Pulmonary Branch, National Heart, Lung, and Blood \\ Institute, National Institutes of Health, Bethesda, Maryland 20205
}

A B S T RA C T Hyperoxia and paraquat ingestion are two clinical examples of lung injury thought to be mediated by oxidant mechanisms. An in vitro cytotoxicity assay using freshly explanted ${ }^{51} \mathrm{Cr}$-labeled lung tissue as the target was used to quantify the ability of hyperoxia and paraquat to directly injure lung parenchymal cells in an environment where indirect mechanisms such as recruitment of inflammatory cells were not possible. There are clear species differences in the susceptibility of lung parenchyma to direct injury by hyperoxia $\left(95 \% \mathrm{O}_{2}\right)$ and paraquat $(10 \mu \mathrm{M}-$ $10 \mathrm{mM}$ ) for $18 \mathrm{~h}$ at $37^{\circ} \mathrm{C}$, with human and rat lung being more sensitive than rabbit lung. Oxygen radical inhibitors, particularly catalase $(1,100 \mathrm{U} / \mathrm{ml})$ and $\alpha$ tocopherol $(10 \mu \mathrm{g} / \mathrm{ml})$, reduced hyperoxia and paraquat-induced lung injury, although their ability to do so depended on the oxidant and the species. The simultaneous use of hyperoxia and paraquat accelerated the in vitro lung parenchymal cell injury in each species tested. These studies demonstrate that both oxygen and paraquat can directly injure the cells of the lower respiratory tract without enlisting the aid of additional blood-derived inflammatory cells. In addition, the ${ }^{51} \mathrm{Cr}$-labeled lung explant assay used for these studies allows for the quantitative assessment of direct lung cell injury and thus may prove useful as an in vitro model by which to investigate lung injury of other etiologies.

\section{INTRODUCTION}

A mandatory requirement for eukaryotic cells is the ability to reduce oxygen to $\mathrm{H}_{2} \mathrm{O}$ and to utilize the energy released. Unfortunately, this process is not without risk, as reduction of oxygen by cells is normally accompanied by a small, but significant, production of oxygen intermediates (1-3). These intermediates, including superoxide $\left(\mathrm{O}_{2}^{-}\right)$, hydrogen peroxide $\left(\mathrm{H}_{2} \mathrm{O}_{2}\right)$, hydroxyl radical $(\cdot \mathrm{OH})$, and singlet oxygen $\left({ }^{1} \mathrm{O}_{2}\right)$, are highly reactive and can cause cell injury and death by

Received for publication 17 October 1980 and in revised form 26 June 1981. disturbing a variety of cell structures and functions. Usually, these reactive oxygen intermediates cause little problem, as most cells have mechanisms, such as the enzyme superoxide dismutase, which scavenges $\mathrm{O}_{2}^{-}$, to protect themselves from so-called "oxidant" injury (4). There are a variety of situations, however, in which the burden of oxygen intermediates is apparently too great, and the parenchymal cells of tissues are injured and eventually destroyed (5-7).

The most common target for oxidant injury is the lung, as it is the cells of this organ that are exposed to the highest concentration of oxygen of any cells in the body. In addition, there are two clinical situations in which lung cells are particularly vulnerable to oxidant injury: $(a)$ in hyperoxic conditions, where high concentrations of oxygen are administered, such as when patients are placed on assisted ventilation due to pulmonary insufficiency; and $(b)$ following the ingestion of paraquat (methyl viologen), a herbicide that causes rapidly progressive lung injury and failure.

Although it is generally accepted that hyperoxia and paraquat ingestion likely cause lung injury by oxidant processes, several aspects of such injury are not clear. Some unresolved questions include: $(a)$ Do these oxidants directly injure lung cells or does the injury require the recruitment of blood-borne inflammatory and immune effector cells?; (b) Are the reported species differences in sensitivity to oxidant injury reflected in differences at the lung cellular level, or do they result from extrapulmonary factors operating in vivo?; (c) Which $\mathrm{O}_{2}$ radical inhibitors offer the best protection from oxidant injury?; $(d)$ Can various forms of oxidants act synergistically to injure lung tissue?

To answer these questions, this study was designed to evaluate the direct effect of oxygen and/or paraquat on lung cells. To accomplish this, an in vitro assay was developed that quantifies cytotoxicity to lung parenchymal cells. By using ${ }^{51} \mathrm{Cr}$-labeled lung explants as the target, this approach permits quantitative assessment of cell injury to lung parenchymal cells in a controlled local environment, thus permitting evaluation of the direct cytotoxic effect of oxidants on cells comprising the alveolar structures as well as the ability of various antioxidants to obviate such injury. 
The results suggest that: $(a) \mathrm{O}_{2}$ and paraquat can directly injure the lung parenchyma; $(b)$ although a variety of species are susceptible to direct lung oxidant injury, there are clear species differences in the sensitivity of lung parenchymal cells to oxidant injury; $(c)$ oxygen radical inhibitors clearly prevent direct oxidant injury to lung parenchymal cells, but this protective effect depends on the oxidant and the species; and $(d)$ oxidant injury is clearly accelerated in the presence of both hyperoxia and paraquat.

\section{METHODS}

Lung explant cytotoxicity system. New Zealand adult white rabbits (B and $\mathrm{H}$ Rabbitry, Rockville, Md.) were killed by $\mathrm{CO}_{2}$ inhalation and Sprague-Dawley adult white rats (National Institutes of Health stock, Bethesda, Md.) were decapitated. The cytotoxicity results were identical regardless of the means of death of the animal. The lungs were perfused with heparinized saline to remove inflammatory cells within the vasculature. Using aseptic technique the trachea, lungs, and heart were dissected en bloc from the test animals. To obtain thin and reproducibly sized pieces of lung tissue the lungs were prepared for slicing by adapting an agarose inflation technique used for long-term culture of lung explants (8). Low-melting point agarose (Bethesda Research Laboratories, Rockville, Md.) was dissolved at $80^{\circ} \mathrm{C}$ in RPMI 1640 media (Microbiological Associates, Inc., Bethesda, Md.) at $0.6 \%(\mathrm{wt} / \mathrm{vol})$, cooled to $37^{\circ} \mathrm{C}$, and instilled as a liquid in the trachea, inflating the lungs to approximate total lung capacity. The lungs were then placed in sterile saline at $4^{\circ} \mathrm{C}$ for $10 \mathrm{~min}$, solidifying the agarose. The resulting agarose-filled lungs could then be easily sliced on a tissue slicer (Arthur H. Thomas Co., Philadelphia, Pa.) into sheets of parenchyma $200-400 \mu \mathrm{m}$ thick. These sheets were then individually cut into explants with an average wet wt of $2 \mathrm{mg}$.

The lung explants were incubated overnight in culture media [RPMI 1640 with $25 \mathrm{mM}$ Hepes buffer, $\mathrm{pH} 7.4,1.5 \%$ bovine serum albumin (Gibco, Grand Island Biological Laboratories, Grand Island, N. Y.), $100 \mathrm{U} / \mathrm{ml}$ penicillin, and $100 \mu \mathrm{g} / \mathrm{ml}$ streptomycin] in a volume of one explant per milliliter at $37^{\circ} \mathrm{C}$ in a humidified $5 \% \mathrm{CO}_{2}$ atmosphere. ${ }^{51} \mathrm{Cr}$ (Amersham Corp., Arlington Heights, Ill.) was added to the explant culture $(25 \mu \mathrm{Ci} / \mathrm{ml})$ at the initiation of the incubation. After $20 \mathrm{~h}$ in culture, the explants were washed extensively with fresh, unlabeled media, and maintained in this media until the wet weight of each explant was determined just before the cytotoxicity assay. The uniformity of ${ }^{51} \mathrm{Cr}$ uptake by lung parenchymal cells was assessed by autoradiography (9). To assess the "leak" of ${ }^{51} \mathrm{Cr}$ by control explants, the spontaneous release of ${ }^{51} \mathrm{Cr}$ was quantified at intervals up to $30 \mathrm{~h}$ after labeling.

The cytotoxicity assay was performed using one ${ }^{51} \mathrm{Cr}$ labeled explant per assay. The labeled explant was placed in the bottom of a $12 \times 75-\mathrm{mm}$ tube and $1 \mathrm{ml}$ culture media (alone or containing various test oxidants and/or antioxidants) was added. After $18 \mathrm{~h}$ of incubation at $37^{\circ} \mathrm{C}$, the tubes were centrifuged $(800 \mathrm{~g}, 5 \mathrm{~min})$, and the ${ }^{51} \mathrm{Cr}$ released in the media was quantitated. From this data, cell injury was defined in terms of a "cytotoxic index": $[(\mathrm{A}-\mathrm{B}) /(\mathrm{C}-\mathrm{B})] \times 100$, where A $=[\mathrm{dpm}$ released into the media from the test explant $] /[$ total $\mathrm{dpm}$ in the tube (media + explant) containing the test explant $] . B=[\mathrm{dpm}$ spontaneously released into the media from a control explant]/[total $\mathrm{dpm}$ in the tube (media + explant) containing the control explant $] . \mathrm{C}=[\mathrm{dpm}$ released from a control explant treated with $2 \%$ triton-X]/[total dpm in the tube (media + explant) containing the control explant treated with triton-X].

Using this formula, a cytotoxic index of $100 \%$ indicates the test oxidant caused the release of all ${ }^{51} \mathrm{Cr}$ that was "releasable" from the explant. In contrast, a cytotoxic index of $0 \%$ indicates that the test oxidant caused no release of ${ }^{51} \mathrm{Cr}$ beyond that due to spontaneous "leak" during the culture period.

To assess the effect of culture on the parenchymal structures, control explants were evaluated by light microscopy at the beginning of the culture period, and after $42 \mathrm{~h}$ (i.e., $20 \mathrm{~h}$ labeling time $+4 \mathrm{~h}$ incubation time in unlabeled media, and time for weighing explants $+18 \mathrm{~h}$ for cytotoxicity assay). In addition, the rate of protein synthesis was measured in control explants to assess the functional stability of the explanted lung tissue. Control rat lung explants were incubated with $\mathrm{L}-\left[3,4^{3} \mathrm{H}\right]$ valine $(56.8 \mathrm{Ci} / \mathrm{mmol})$ at $5 \mu \mathrm{Ci} / \mathrm{ml}$ in Dulbecco's minimal essential medium (without valine). The rate of protein synthesis was quantitated at 1,24 , and $48 \mathrm{~h}$ after sacrifice of animal as described (10).

Oxidant-induced injury to lung explants. To demonstrate that the ${ }^{51} \mathrm{Cr}$-labeled lung explant system was sensitive to known oxidants, rabbit lung explants were incubated with an $\mathrm{O}_{2}^{-}$generating system and with $\mathrm{H}_{2} \mathrm{O}_{2}$ for $18 \mathrm{~h}$ at $37^{\circ} \mathrm{C}$. $\mathrm{O}_{2}^{-}$ was generated by sodium xanthine $80 \mu \mathrm{g} / \mathrm{ml}$ (Sigma Chemical Co., St. Louis, Mo.) and xanthine oxidase $0.001 \mathrm{U} / \mathrm{ml}-0.01$ $\mathrm{U} / \mathrm{ml}$ (Sigma Chemical Co.) and monitored by the reduction of ferricytochrome C (11). $\mathrm{H}_{2} \mathrm{O}_{2}$ (Fisher Scientific Co., Pittsburgh, $\mathrm{Pa}$.) was added directly to the media $(0.1-3.0 \mathrm{mM})$. The protective role of specific inhibitors of $\mathrm{O}_{2}^{-}$and $\mathrm{H}_{2} \mathrm{O}_{2}$ was assessed by the addition of $300 \mathrm{U} / \mathrm{ml}$ of canine superoxide dismutase or $1,100 \mathrm{U} / \mathrm{ml}$ of bovine liver catalase (Sigma Chemical Co.) just prior to the addition of $\mathrm{O}_{2}^{-}$and $\mathrm{H}_{2} \mathrm{O}_{2}$.

Lactate dehydrogenase (LDH), ${ }^{1}$ a cytoplasmic enzyme, was assayed to determine if the oxidant-induced ${ }^{51} \mathrm{Cr}$ release from lung explants was also associated with the loss of this marker of cellular integrity. Rat lung explants exposed to $\mathrm{H}_{2} \mathrm{O}_{2}(10$ $300 \mu \mathrm{M})$ for $18 \mathrm{~h}$ at $37^{\circ} \mathrm{C}$ were assayed in parallel cytotoxicity assays using ${ }^{51} \mathrm{Cr}$ as described above and endogenous LDH as monitors of lung cell injury. LDH was measured by the spectrophotometric decrease in absorbance of NADH at $400 \mathrm{~nm}(12)$. LDH was assayed in the lung explant culture media to determine the release of the enzyme by the lung explant cells. In addition, to assess the total LDH available in each explant the lung explants were individually sonicated (model W185 sonicator with microtip, Heat Systems-Ultrasonics, Inc., Plainview, N. Y.) in $1.0 \mathrm{ml}$ cold phosphate buffer, $\mathrm{pH} 7.4$, and then assayed for LDH activity as described above. Thus, because the LDH released from the lung explants can be expressed as a percentage of the total LDH available, a cytotoxic index can be calculated identically to that previously described for ${ }^{51} \mathrm{Cr}$.

Effect of paraquat on lung explants. To evaluate the cytotoxic effect of paraquat on lung parenchymal cells, rat and rabbit explants were labeled with ${ }^{51} \mathrm{Cr}$ for $20 \mathrm{~h}$ as described above. After the labeled explants were washed and incubated in unlabeled media $\left(4 \mathrm{~h}, 37^{\circ} \mathrm{C}\right)$, paraquat $(1 \mathrm{mM})$ (Aldrich Chemical Company, Milwaukee, Wis.) was added and the explants incubated at $37^{\circ} \mathrm{C}$ for $18 \mathrm{~h}$. After incubation, the cytotoxic index was calculated as described above. To confirm that paraquat-induced lung cell injury was not secondary to consumption of glucose in the media, the effect of glucose concentrations in the media was evaluated by: $(a)$ the direct measurement of glucose in the media before and after the cytotoxicity assay, and $(b)$ the paraquat cytotoxicity assay was repeated in the presence of a marked excess of glucose in

\footnotetext{
${ }^{1}$ Abbreviations used in this paper: LDH, lactate dehydrogenase; SOD, superoxide dismutase.
} 
the media $(500 \mathrm{mg} / \mathrm{dl})$. To evaluate the influence of "antioxidants" on this system, parallel cultures of ${ }^{51} \mathrm{Cr}$-labeled explants were incubated with paraquat $(1 \mathrm{mM})$ together with superoxide dismutase $(300 \mathrm{U} / \mathrm{ml})$, catalase $(1,100 \mathrm{U} / \mathrm{ml})$, D- $\alpha$-tocopherol succinate $(10 \mu \mathrm{g} / \mathrm{ml}$ ) (Sigma Chemical Co.), or L-ascorbic acid $(50 \mu \mathrm{g} / \mathrm{ml})$ (Sigma Chemical Co.). Each agent was dissolved in media, sterilized by a $0.45-\mu \mathrm{m}$ filter (Swinnex-13, Millipore Corp., Bedford, Mass.), and added just before the addition of paraquat.

The only exception to this approach was the need to initially dissolve $\alpha$-tocopherol in ethanol before diluting in the media. The final concentration of ethanol was $0.01 \%$ (vol/vol), and ethanol at this concentration was neither injurious as a cytotoxic agent nor protective to lung cells as a radical scavenger.

When preliminary studies demonstrated that 18-h exposure to $1 \mathrm{mM}$ paraquat was toxic to rat explants, but not rabbit explants, two approaches were used to determine if longer exposure to paraquat would cause toxicity to the rabbit cells. Both of these approaches required modification of the cytotoxicity assay because the spontaneous "leak" of ${ }^{51} \mathrm{Cr}$ from control explants was excessive for incubations of $>18 \mathrm{~h}$.

First, a cytotoxicity assay was developed in which $\left[{ }^{3} \mathrm{H}\right]-$ uridine was substituted for ${ }^{51} \mathrm{Cr}$ as the label of parenchymal cells. To accomplish this, rabbit explants were incubated with $\left[5,6^{3} \mathrm{H}\right]$ uridine $(45.9 \mathrm{Ci} / \mathrm{mmol}, 10 \mu \mathrm{Ci} / \mathrm{ml}$ media; Amersham Radiochemicals, Arlington Heights, Ill.) for $20 \mathrm{~h}$ at $37^{\circ} \mathrm{C}$. The explants were then washed extensively and the explants incubated with paraquat $(1 \mathrm{mM})$ as described above except that the exposure to paraquat was carried out for $42 \mathrm{~h}$. After incubation, the method for determination of the percentage of $\left[{ }^{3} \mathrm{H}\right.$ ] uridine released in the media was identical to the ${ }^{51} \mathrm{Cr}$ assay except that NCS tissue solubilizer (Amersham Radiochemicals) was used to dissolve each explant before the addition of scintillation fluid to allow for full expression of counts retained in the explant. The use of Triton- $X$ to induce maximal killing of cells in the assay and the calculation of the cytotoxic index was as described for the ${ }^{51} \mathrm{Cr}$ assay.

To assess the percentage of $\left[{ }^{3} \mathrm{H}\right]$ uridine released and retained in macromolecular form at the end of the cytotoxicity experiment, media from control and test explants was precipitated with $10 \%$ trichloroacetic acid. Similarly, to assess the percentage of $\left[{ }^{3} \mathrm{H}\right]$ uridine incorporated into the control and text explants, each explant was homogenized in $1.0 \mathrm{ml}$ cold phosphate buffer, pH 7.4, with a Brinkman polytron (setting of 10 for $30 \mathrm{~s}$ ) and the homogenate precipitated with $10 \%$ TCA.

Second, the time of exposure to paraquat could be extended in the ${ }^{51} \mathrm{Cr}$ cytotoxicity assay by exposing the rabbit explants to paraquat from the beginning of the ${ }^{51} \mathrm{Cr}$ labeling period. To accomplish this, $(1 \mathrm{mM})$ paraquat was added to the rabbit explants at the same time ${ }^{51} \mathrm{Cr}$ was added for labeling. After $20 \mathrm{~h}$, the explants were washed, incubated in unlabeled media at $37^{\circ} \mathrm{C}$, and weighed as described above (total $4 \mathrm{~h}$ ). The remainder of the assay was conducted as in the standard ${ }^{51} \mathrm{Cr}$ assay $(18 \mathrm{~h})$, thus resulting in the rabbit lung explants being exposed to paraquat for a total of $42 \mathrm{~h}$. This adaptation of the ${ }^{51} \mathrm{Cr}$ assay to $42 \mathrm{~h}$ was only used for the special circumstance of incubating rabbit lung explants with $1 \mathrm{mM}$ paraquat. All other cytotoxicity experiments using rabbit lung explants were by the standard $(18 \mathrm{~h}){ }^{51} \mathrm{Cr}$ technique.

Effect of oxygen and lung explants. To assess the role of hyperoxia-induced lung injury, rat and rabbit lung explants were labeled with ${ }^{51} \mathrm{Cr}(20 \mathrm{~h})$, washed, incubated in unlabeled media at $37^{\circ} \mathrm{C}$, weighed (total $4 \mathrm{~h}$ ), and then incubated in a humidified atmosphere of $95 \% \quad 0_{2}-5 \% \quad \mathrm{CO}_{2}$ $(18 \mathrm{~h})\left(\mathrm{pO}_{2}\right.$ of media was $\left.590 \pm 20\right)$. Control explants were incubated under identical circumstances except in a humidified air-5\% $\mathrm{CO}_{2}$ atmosphere. Parallel cultures were incubated with the oxygen radical inhibitors superoxide dis- mutase, catalase, $\alpha$-tocopherol, and ascorbate as described above. After incubation, the cytotoxic index was then quantified.

Effect of simultaneous paraquat and oxygen on lung explants. To determine if hyperoxia and paraquat would accelerate injury to the explants beyond the effect of either agent alone, rat and rabbit lung explants were labeled with ${ }^{51} \mathrm{Cr}(20 \mathrm{~h})$, washed, incubated in unlabeled media at $37^{\circ} \mathrm{C}$ weighed (total $4 \mathrm{~h}$ ), and then incubated with $10 \mu \mathrm{M}-10 \mathrm{mM}$ paraquat in an atmosphere of $95 \% \mathrm{O}_{2}-5 \% \mathrm{CO}_{2}(18 \mathrm{~h})$. For comparison, paraquat dose-response curves were established for each species in a normal atmosphere of air-5\% $\mathrm{CO}_{2}$. Controls were explants maintained in air-5\% $\mathrm{CO}_{2}$ without exposure to paraquat. After incubation, the cytotoxic index was quantified as described above.

Effect of paraquat and hyperoxia on endogenous antioxidant levels in lung explants. To determine if oxidant injury to the lung explants was associated with an alteration in endogenous cellular antioxidant levels, SOD and catalase activities were measured in control and test explants. Rat lung explants were processed as described earlier except they were not inflated with agarose-media that interfered with the absorbance readings in the enzyme assays. Additionally, it was necessary to use a pool of explants (30-40 explants per time point) for a total net weight of $60-80 \mathrm{mg}$ to obtain enzyme activities in a measurable range. Control explants at incubation times of 0,24 , and $42 \mathrm{~h}$ and test explants exposed to $95 \% \mathrm{O}_{2}$ or paraquat $(1 \mathrm{mM})$ for the final 18-h period of the total incubation time $(42 \mathrm{~h})$ were each pooled and homogenized in $1.0 \mathrm{ml}$ cold phosphate buffer $(\mathrm{pH}$ 7.4) by a Brinkman polytron at a setting of 10 for $60 \mathrm{~s}$. The lung homogenates were centrifuged at $16,000 \mathrm{~g} \times 15 \mathrm{~min}$, and the supernates were assayed immediately for catalase activity by measuring the decrease in absorbance of $\mathrm{H}_{2} \mathrm{O}_{2}$ at $240 \mathrm{nM}$ (13) and for SOD activity by the ferricytochrome $C$ assay (11). Standard curves were obtained for each assay run using defined preparations of catalase and SOD (Sigma Chemical Company).

Evaluation of oxidant injury to human lung explants. Human lung was obtained as fresh surgical specimens from lung resections for isolated nodules from cancers metastatic to the lung. Subjects had a mean age of $42 \pm 6 \mathrm{yr}$, had no evidence of underlying lung disease and were all nonsmokers. Histologic sections were independently reviewed and each consisted of normal appearing lung tissue free of any microscopic evidence of malignant cells or secondary infection. The agarose-media inflation technique was adapted for the use of biopsy material to obtain thin, reproducibly sized explants. To accomplish this, the dissolved agarose was injected into multiple sites of the biopsy by a 25-gauge needle. The lung tissue was then sliced and processed for the cytotoxicity assay as described earlier. The human lung explants were labeled with ${ }^{51} \mathrm{Cr}(20 \mathrm{~h})$, washed, incubated in unlabeled media at $37^{\circ} \mathrm{C}$, weighed (total $4 \mathrm{~h}$ ), and then incubated with $(1 \mathrm{mM})$ paraquat, $95 \% \mathrm{O}_{2}$, or $(1 \mathrm{mM})$ paraquat in a $95 \% \mathrm{O}_{2}$ atmosphere $(18 \mathrm{~h})$ as described for the rat and rabbit explants. As with the animal explants, various antioxidants were tested for their ability to prevent toxicity. After incubation, the cytotoxic index was quantified as described above.

\section{RESULTS}

Lung explant system. Several criteria were used to show that the control explants remained viable over the study period. First, light microscopy demonstrated that at the end of the total culture period $(42 \mathrm{~h})$, con- 


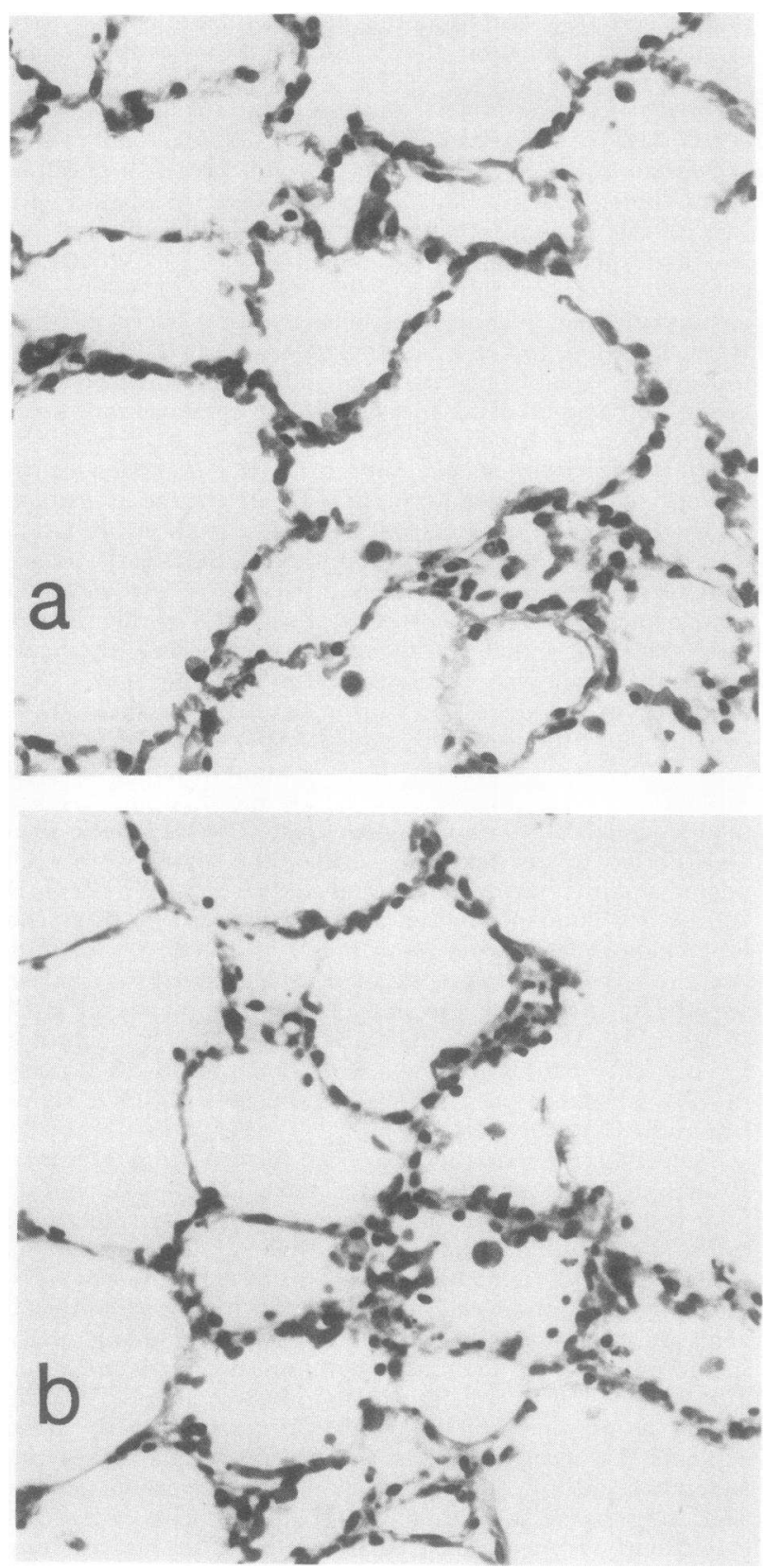

FIGURE 1 Rabbit lung explants maintained in RPMI 1640 with $1.5 \%$ bovine serum albumin in a humidified air-5\% $\mathrm{CO}_{2}$ atmosphere. (A) Beginning of culture period $(0 \mathrm{~h})$ demonstrates inflation of alveoli with agarose-media $(\times 330)$. (B) End of culture period $(42 \mathrm{~h})$ revealing preservation of alveolar structures with a relative maintenance of cellularity within the alveolar septa, sharpness of cellular borders, and a lack of cellular debris within the alveoli $(\times 330)$.

trol explants had preservation of the alveolar structures with maintenance of cellularity within the alveolar septa, sharpness of cellular borders, and a lack of cellular debris within the alveoli (Fig. 1). Second, the

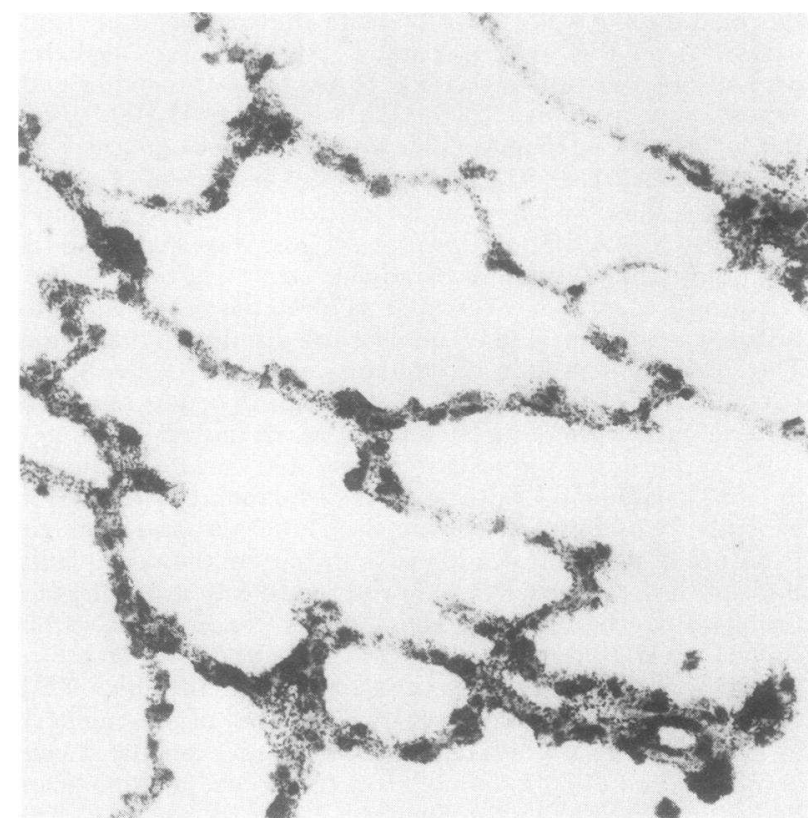

FIgURE 2 Autoradiography of a rabbit lung explant incubated with ${ }^{51} \mathrm{Cr}(25 \mu \mathrm{Ci} / \mathrm{ml})$ for $18 \mathrm{~h}$. Lung parenchymal cells demonstrate uniform uptake of the label.

spontaneous release of ${ }^{51} \mathrm{Cr}$ over the standard incubation time $(18 \mathrm{~h})$ was consistently $<30 \%$ of the total releasable counts; this is consistent with maintenance of cellular integrity within the control explants (14). Third, labeling with $\left[{ }^{3} \mathrm{H}\right]$ uridine confirmed that the explants were able to incorporate an RNA precursor and maintain this precursor ("leak" $<30 \%$ total releasable counts over $42 \mathrm{~h}$ ) within the cell structures for at least the 42-h culture period. Fourth, under the conditions used for these studies, rabbit lung explants are capable of synthesizing protein in a linear fashion for at least $48 \mathrm{~h}$ (15). Rat lung explants similarly incorporated $\left[{ }^{3} \mathrm{H}\right]$ valine as a marker of protein synthesis with no significant differences in rate at 1,24 , and $48 \mathrm{~h}$ after sacrifice of the animal ( $P>0.20$, all comparisons). Fifth, agarose-inflated lung explants have been successfully maintained in culture for as long as $1 \mathrm{mo}$ (8). Thus, lung explants under the conditions used in this study have a normal histologic appearance, demonstrate little spontaneous cell toxicity (limited ${ }^{51} \mathrm{Cr}$ release), and continue to perform complex biochemical processes (e.g., uridine incorporation, protein synthesis).

The lung explant system described provides the opportunity to study cytotoxicity of the diverse cell populations of the lung parenchyma. Autoradiography of lung explants exposed to ${ }^{51} \mathrm{Cr}$ revealed that all the lung cells display uptake of the label (Fig. 2). Thus, the cytotoxicity assay is based on lung explant cells that are viable under the study conditions and are generally 


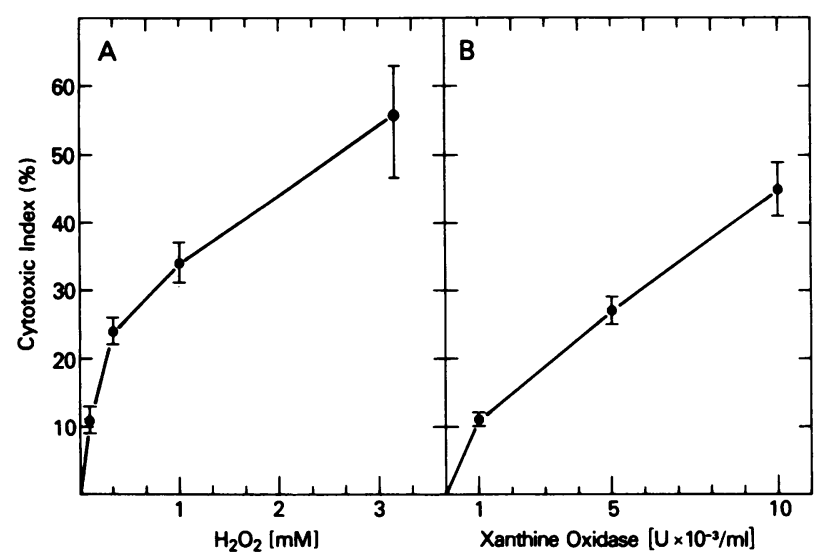

FIGURE 3 Cytotoxicity assay using rabbit lung explants labeled with ${ }^{51} \mathrm{Cr}$ in air-5\% $\mathrm{CO}_{2}$ atmosphere for $18 \mathrm{~h}$ confirming that ${ }^{51} \mathrm{Cr}$ release was directly proportional to increasing concentrations of known oxidants. Cell injury was quantified using the cytotoxic index that expresses the percentage of ${ }^{51} \mathrm{Cr}$ released from the test explant on a scale where $0 \%$ represents the release of ${ }^{51} \mathrm{Cr}$ from the control explant and $100 \%$ represents the release of ${ }^{51} \mathrm{Cr}$ from the explant incubated with triton X-100. (A) Explants incubated with hydrogen peroxide $\left(\mathrm{H}_{2} \mathrm{O}_{2}\right)$. (B) Explants incubated with sodium xanthine $(80 \mu \mathrm{g} / \mathrm{ml})$ and xanthine-oxidase $(0.001 \mathrm{U} / \mathrm{ml}$ to $0.01 \mathrm{U} / \mathrm{ml}$ ) which yields superoxide $\left(\mathrm{O}_{2}^{-}\right)$at an approximate initial reaction velocity of $1-10 \mathrm{nmol} / \mathrm{min} / \mathrm{ml}$. Data represent mean \pm SEM

labeled by ${ }^{51} \mathrm{Cr}$, the release of which into the media forms the basis for quantifying cell injury.

Oxidant-induced injury to lung explants. The ability of the ${ }^{51} \mathrm{Cr}$-labeled explant system to detect oxidant injury was established by demonstrating the ability of $\mathrm{O}_{2}^{-}$and $\mathrm{H}_{2} \mathrm{O}_{2}$ to cause ${ }^{51} \mathrm{Cr}$ release from the labeled explants (Fig. 3). Dose-response curves for both $\mathrm{O}_{2}^{-}$and $\mathrm{H}_{2} \mathrm{O}_{2}$ revealed that significant cytotoxicity occurred with as little as $1 \mathrm{nmol} \mathrm{O}_{2}^{-}$generated/ min per milliliter or $0.1 \mathrm{mM} \mathrm{H}_{2} \mathrm{O}_{2}$. The cytotoxic effects of $\mathrm{O}_{2}^{-}$generation at $5 \mathrm{nmol} / \mathrm{min}$ per milliliter (cytotoxic index $=27.1 \pm 2.0 \%)^{2}$ could be ablated by catalase $(1,100 \mathrm{U} / \mathrm{ml})$ (cytotoxic index $=5.9 \pm 1.3 \%, P<0.01$ ) but not by superoxide dismutase $(300 \mathrm{U} / \mathrm{ml})$ (cytotoxic index $=27.7 \pm 2.3 \%, P>0.7$ ). Injury induced by $\mathrm{H}_{2} \mathrm{O}_{2}$ at $0.1 \mathrm{mM}$ (cytotoxic index $=10.8 \pm 2.0 \%$ ) was also reduced by catalase (cytotoxic index $=-2.8 \pm 0.4 \%$, $P<0.01$ ) but not by superoxide dismutase (cytotoxic index $=8.3 \pm 1.7 \%, P>0.2$ ). Clearly rabbit lung explants were susceptible to injury by the text oxidants. The protection afforded by catalase and not superoxide dismutase to lung cells exposed to $\mathrm{O}_{2}^{-}$implies a critical role for $\mathrm{H}_{2} \mathrm{O}_{2}$ in the generation of lung cell injury by the xanthine-xanthine oxidase system.

Oxidant-induced ${ }^{51} \mathrm{Cr}$ release was clearly associated with lung cell injury as monitored by LDH release.

\footnotetext{
${ }^{2}$ All data represent mean \pm SEM.
}

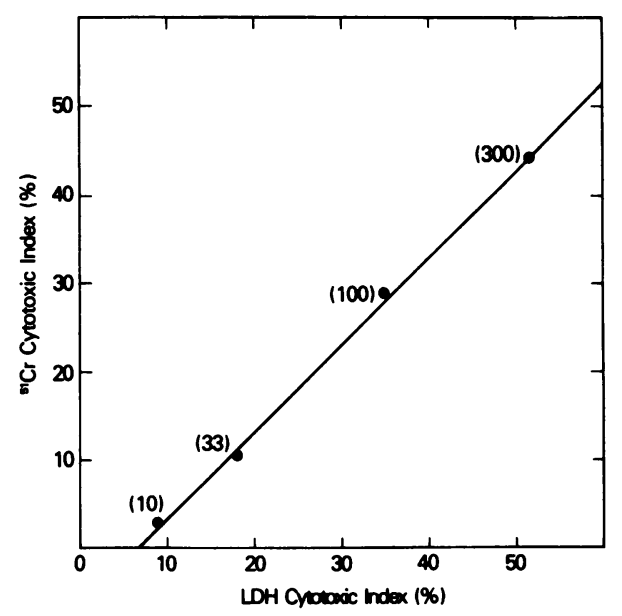

FIGURE 4 Direct correlation of ${ }^{51} \mathrm{Cr}$ release with $\mathrm{LDH}$ release in rat lung explants exposed to hydrogen peroxide $\left(\mathrm{H}_{2} \mathrm{O}_{2}\right)$ for $18 \mathrm{~h}(r=0.82)$. Each $\mathrm{H}_{2} \mathrm{O}_{2}$ concentration $(10-300$ $\mu \mathrm{M})$ represents 12 explants for ${ }^{51} \mathrm{Cr}$ release and 12 explants for LDH release. The method for determining the cytotoxic index was identical for both ${ }^{51} \mathrm{Cr}$ and $\mathrm{LDH}$.

Rat lung explants exposed to $\mathrm{H}_{2} \mathrm{O}_{2}(10-300 \mu \mathrm{M})$ resulted in a release of $\mathrm{LDH}$ directly proportional to the release of ${ }^{51} \mathrm{Cr}$ (Fig. 4). Thus, the results of the ${ }^{51} \mathrm{Cr}$ assay directly correlate with cell injury as monitored by $\mathrm{LDH}$ release.

Effect of paraquat on lung explants. Rat lung cells exposed to paraquat for $18 \mathrm{~h}$ demonstrated significant cytotoxicity as monitored by ${ }^{51} \mathrm{Cr}$ release (Fig. 5A). Additionally there was histologic evidence of cell injury in the rat lung explant (Fig. 6) manifest as ir-

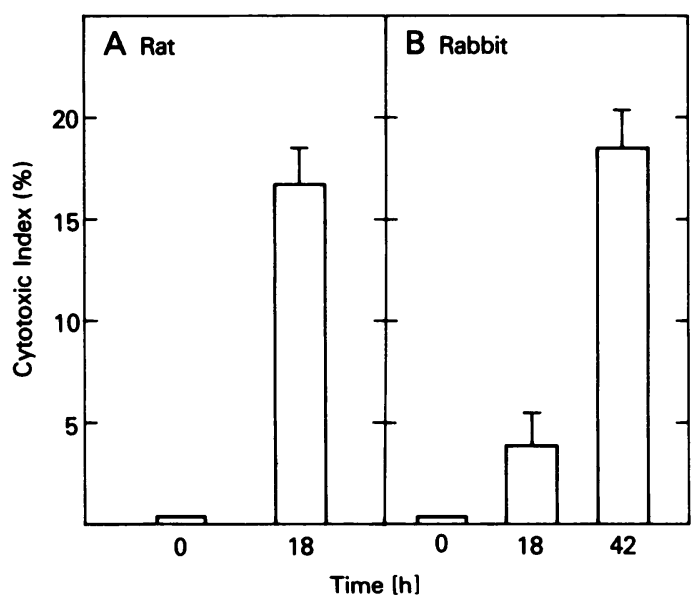

FIGURE 5 Direct effect of paraquat on rat and rabbit lung. ${ }^{51} \mathrm{Cr}$-labeled lung explants were incubated with (1 $\left.\mathrm{mM}\right)$ paraquat in an air-5\% $\mathrm{CO}_{2}$ atmosphere. (A) Rat lung explants demonstrate marked cytotoxicity by $18 \mathrm{~h}(P<0.01$ compared with controls). (B) Rabbit lung explants at $18 \mathrm{~h}$ demonstrate no significant cell injury. However, at $42 \mathrm{~h}$, significant cytotoxicity was observed $(P<0.01$ compared with controls). Data represent mean \pm SEM. 

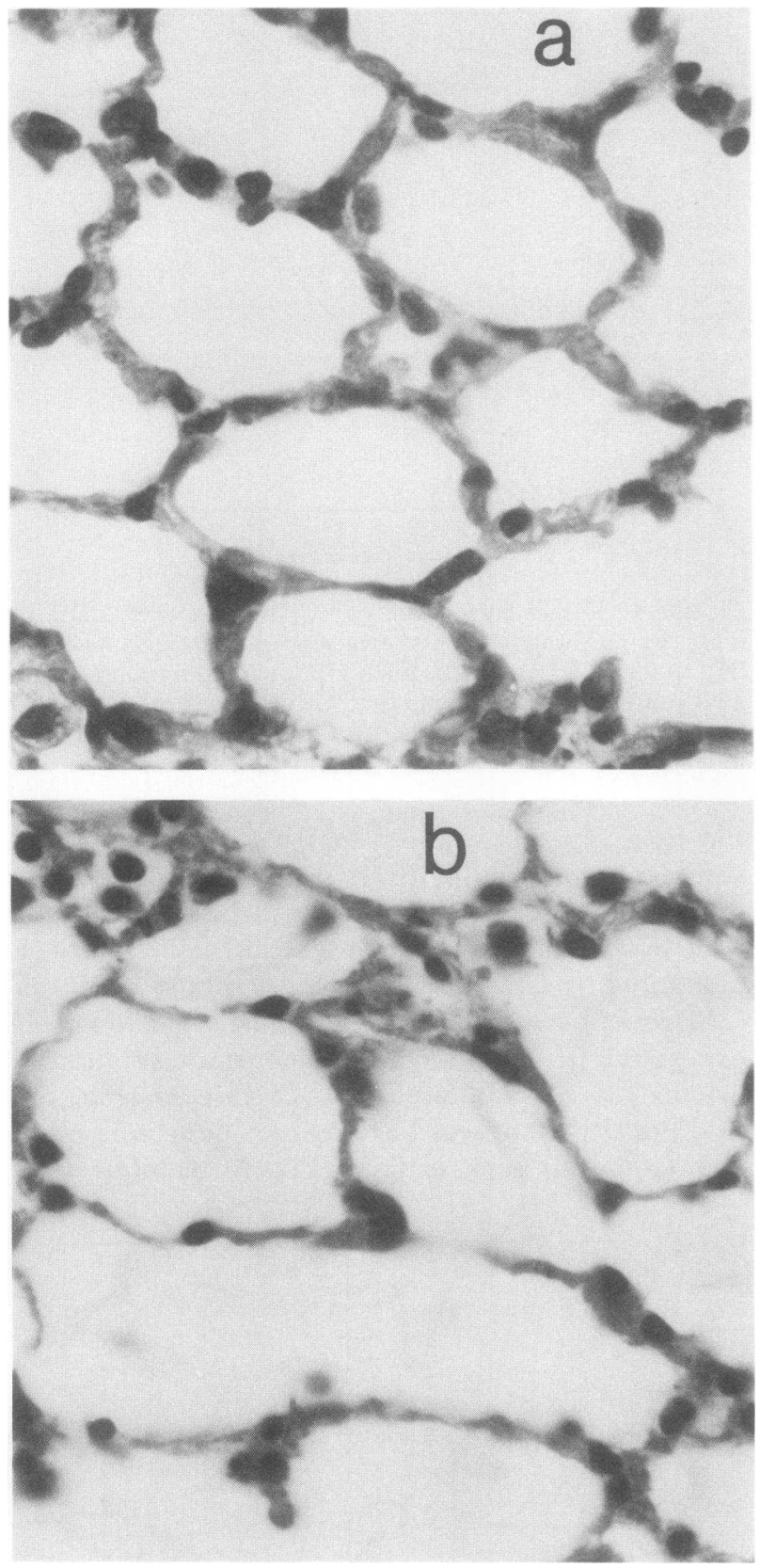

FIGURE 6 Rat lung explants maintained in RPMI 1640 with $1.5 \%$ bovine serum albumin for $42 \mathrm{~h}$. (A) Control explants $(\times 860)$. (B) Explants incubated with $(1 \mathrm{mM})$ paraquat for the last $18 \mathrm{~h}$ of total $42-\mathrm{h}$ culture period reveals irregularity and thinning of the alveolar septa, presence of cellular debris within the alveoli, and, in many areas, pyknosis and loss of lung cell nuclei $(\times 860)$.

regularity and thinning of the alveolar septa, increased cellular debris within the alveoli, and pyknosis and eventual loss of lung cell nuclei. These findings were nonspecific and were similar in each species examined and for each oxidant tested. In contrast, under the same conditions, rabbit lung cells did not exhibit significant injury (Fig. 5B). However, sensitivity of rabbit lung cells to paraquat could be demonstrated if the cells were exposed to the same concentration of paraquat for $42 \mathrm{~h}$. This was seen when ${ }^{51} \mathrm{Cr}$ was used as the indicator of toxicity (Fig. 5B) and when $\left[{ }^{3} \mathrm{H}\right]-$ uridine was used as the indicator (data not shown). In the $\left[{ }^{3} \mathrm{H}\right]$ uridine assay, the cytotoxic index with paraquat was $7.7 \pm 1.2 \%$ while at $42 \mathrm{~h}$ the cytotoxic index increased to $54.9 \pm 4.5 \%$. Thus, rabbit parenchymal cells were sensitive to paraquat, but relative to rat lung there appears to be a latent period of at least $18 \mathrm{~h}$ before significant cytotoxicity occurred.

$\left[{ }^{3} \mathrm{H}\right]$ uridine retained in macromolecular form $(10 \%$ trichloroacetic acid precipitable) at the end of the assay was $1.4 \% \pm 0.2 \%$ of the total counts released into the media by control explants and was $3.1 \pm 0.4 \%$ of total counts released by paraquat-injured explants. The percentage of $10 \%$ trichloroacetic acid-precipitable $\left[{ }^{3} \mathrm{H}\right]-$ uridine incorporated into the control lung explants was $39.2 \pm 1.5$ of the total counts, whereas the percentage decreased to $29.5 \pm 1.5$ in the paraquat-injured lung $(P<0.01)$.

There was no significant consumption of glucose in the media by the lung explant cells exposed to paraquat. Glucose in the media before paraquat exposure was $201 \pm 5 \mathrm{mg} / \mathrm{dl}$, and after an 18 -h exposure of rat lung explants to $(1 \mathrm{mM})$ paraquat was $198 \pm 6$ $\mathrm{mg} / \mathrm{dl}(P>0.7)$. Similarly, the addition of glucose up to $500 \mathrm{mg} / \mathrm{dl}$ in the media did not alter the paraquatinduced injury (cytotoxic index in media with glucose $200 \mathrm{mg} / \mathrm{dl}$ was $28.9 \pm 5.4$ and in media with $500 \mathrm{mg} / \mathrm{dl}$ was $31.0 \pm 4.0, P>0.3)$.

Rat lung explants exposed to paraquat for $18 \mathrm{~h}$ (Fig. 7A) were significantly protected by a variety of inhibitors, including superoxide dismutase, catalase, ascorbate, and $\alpha$-tocopherol $(P<0.01$, all comparisons). Rabbit lung cells exposed to paraquat for $42 \mathrm{~h}$ (Fig. 7B) were protected from injury by catalase and $\alpha$-tocopherol ( $P<0.01$, both comparisons). This was true even though the rabbit lung cells were exposed to paraquat for $24 \mathrm{~h}$ before the time the inhibitors were added. In contrast to rat lung cells, superoxide dismutase and ascorbic acid did not protect the rabbit parenchymal cells from paraquat-induced injury ( $P$ $>0.1$, both comparisons). Thus, rabbit and rat lung cells demonstrated a differential susceptibility to paraquat-induced injury and also differential protective effects by oxygen radical inhibitors.

Effect of hyperoxia on lung explants. Hyperoxiainduced lung injury was assessed by incubation of the lung explants in $95 \% \mathrm{O}_{2}$ for $18 \mathrm{~h}$. Both rat and rabbit cells were susceptible to hyperoxia at $18 \mathrm{~h}$, but the rat lung was more susceptible $(P<0.01)$ (Fig. 8). Hyperoxia-induced cytotoxicity in the rat lung explants was reduced by superoxide dismutase, catalase, ascorbate, 


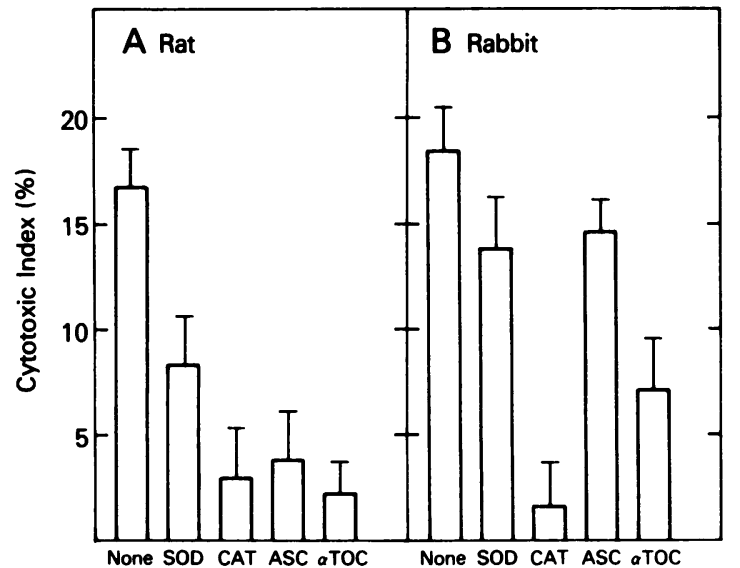

FIGURE 7 Ability of oxygen radical inhibitors to prevent paraquat-mediated toxicity to rat and rabbit lung. ${ }^{51} \mathrm{Cr}-$ labeled explants were incubated with $(1 \mathrm{mM})$ paraquat in an air-5\% $\mathrm{CO}_{2}$ atmosphere plus the oxygen radical inhibitors SOD, $300 \mathrm{U} / \mathrm{ml}$; catalase (CAT), $1,100 \mathrm{U} / \mathrm{ml}$; ascorbate (ASC), $50 \mu \mathrm{g} / \mathrm{ml}$; and $\alpha$-tocopherol ( $\alpha$ TOC), $10 \mu \mathrm{g} / \mathrm{ml}$. (A) Rat lung explants incubated with paraquat and inhibitors for $18 \mathrm{~h}$ demonstrate marked reduction in cytotoxicity by each inhibitor tested ( $P<0.01$, all comparisons). (B) Rabbit lung explants (which required a 42-h incubation with paraquat to induce cytotoxicity) were incubated with the inhibitors for the last $18 \mathrm{~h}$ of the assay. Catalase or $\alpha$-tocopherol reduced paraquat-mediated cytotoxicity $(P<0.01$, both comparisons); whereas SOD or ascorbate had no significant effect $(P>0.10$, both comparisons). Data represent mean \pm SEM.

and $\alpha$-tocopherol $(P<0.05$, all comparisons to $95 \%$ $\mathrm{O}_{2}$ alone). Cytotoxicity of rabbit lung cells exposed to $95 \% \mathrm{O}_{2}$ was prevented by catalase and $\alpha$-tocopherol $(P<0.05$, all comparisons). Thus, the hyperoxia data paralleled the paraquat data with rat lung cells demonstrating a greater susceptibility to direct oxidant injury than rabbit lung cells. In addition, rat lung cells seemed to be protected by a wider variety of inhibitors compared with rabbit lung cells.

Effect of simultaneous hyperoxia and paraquat on lung explants. Hyperoxia enhanced paraquat-induced injury of both rat and rabbit lung cells (Fig. 9). For both species, the hyperoxia-paraquat doseresponse curves displayed a marked shift upward compared with the air-paraquat curves. In addition, this effect was most accentuated in the upper range of paraquat doses tested ( $1 \mathrm{mM}$ for the rat, $10 \mathrm{mM}$ for the rabbit), where the paraquat-hyperoxia curves begin to turn sharply upward. Thus, it appeared that the addition of hyperoxia to paraquat-damaged lung cells accelerated injury to both rat and rabbit lung parenchymal cells.

Effect of paraquat and hyperoxia on endogenous antioxidant levels in lung explants. To assess the endogenous reserve of antioxidant enzymes in lung explants injured by exposure to hyperoxia or paraquat, rat lung explants were assayed for activities of catalase

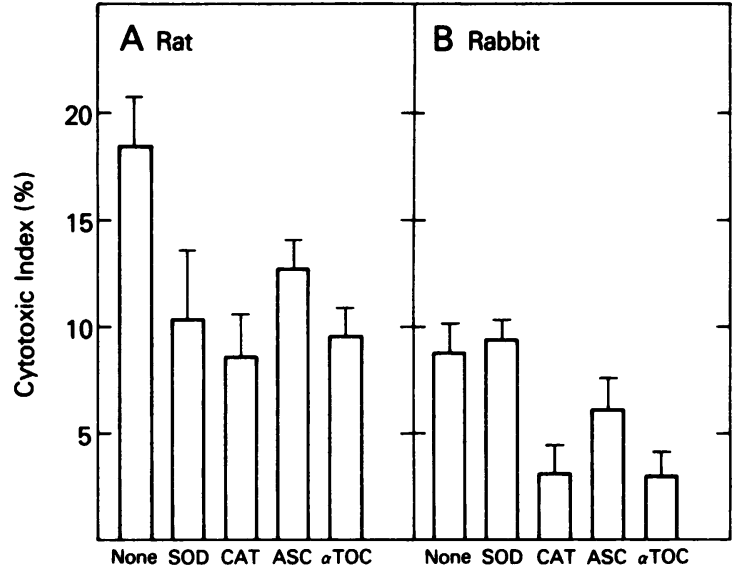

Figure 8 Direct cytotoxicity to lung cells induced by hyperoxia and the ability of oxygen radical inhibitors to prevent such injury. ${ }^{31} \mathrm{Cr}$-labeled explants were incubated in $95 \% \mathrm{O}_{2}-5 \% \mathrm{CO}_{2}$ for $18 \mathrm{~h}$ alone or with the oxygen radical inhibitors SOD, $300 \mathrm{U} / \mathrm{ml}$; catalase (CAT), $1,100 \mathrm{U} / \mathrm{ml}$; ascorbate (ASC), $50 \mu \mathrm{g} / \mathrm{ml}$; and $\alpha$-tocopherol ( $\alpha$ TOC), 10 $\mu \mathrm{g} / \mathrm{ml}$. (A) Rat lung explants exhibited significant hyperoxiainduced cytotoxicity; this injury could be reduced by each inhibitor tested ( $P<0.05$, all comparisons). (B) Rabbit lung explants exhibited less hyperoxia-induced cytotoxicity than rat lung explants $(P<0.05)$. The cytotoxicity in the rabbit explant was reduced by catalase or $\alpha$-tocopherol $(P<0.05$, both comparisons), but not by superoxide dismutase or ascorbate $(P<0.20$, both comparisons). Data represent mean \pm SEM.

and SOD. Control lung explants at 0,24 , and $42 \mathrm{~h}$ had catalase activities (U/mg wet wt) of $0.89 \pm .05,0.79 \pm .06$, $0.71 \pm .07, P>0.05$, all comparisons. Exposure to

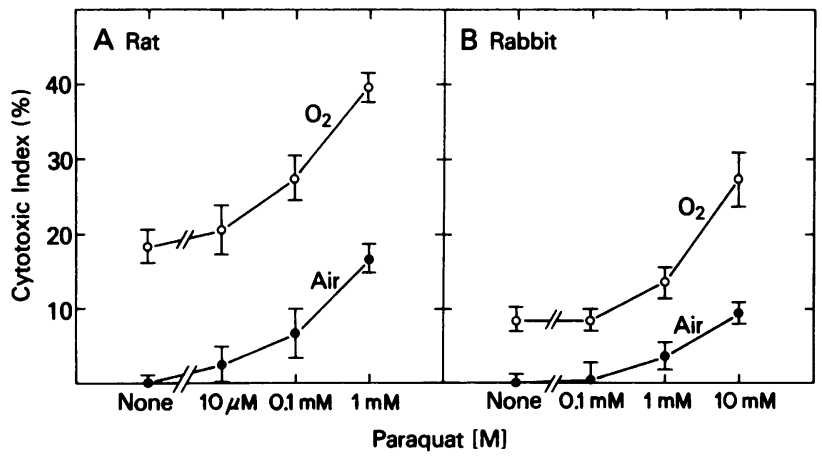

Figure 9 Acceleration of direct oxidant injury to lung parenchymal cells by the combination of paraquat and hyperoxia. Rat and rabbit lung explants were labeled in an identical fashion with ${ }^{51} \mathrm{Cr}$ and incubated under identical conditions with paraquat in either an air-5\% $\mathrm{CO}_{2}$ or $95 \% \mathrm{O}_{2}-5 \%$ $\mathrm{CO}_{2}$ atmosphere for $18 \mathrm{~h}$. (A) Rat lung explants incubated with (10 $\mu \mathrm{M}-1 \mathrm{mM})$ paraquat demonstrated acceleration of oxidant injury by simultaneous incubation in hyperoxic atmosphere. Cytotoxic index with hyperoxia alone was $18.5 \pm 2.2 \%$. (B) Rabbit lung explants incubated with $(0.1-10$ $\mathrm{mM}$ ) paraquat also demonstrated acceleration of oxidant injury by simultaneous incubation in hyperoxic atmosphere. Cytotoxic index of hyperoxia alone was $8.7 \pm 1.3$. Data represent mean \pm SEM. 
hyperoxia decreased the catalase activity to $0.23 \pm 0.05$ $\mathrm{U} / \mathrm{mg}$ wet wt (32.8\% of control values), and exposure to paraquat decreased the activity to $0.16 \pm 0.4 \mathrm{U} / \mathrm{mg}$ wet wt ( $21.8 \%$ control values), $P<0.01$, both comparisons. The wet wt of each explant did not change in response to the oxidant injury. The changes in SOD activity were less dramatic. Control lung explants at 0,24 , and $42 \mathrm{~h}$ had SOD activities (U/mg wet wt) of $0.40 \pm .03,0.36 \pm .05$, and $0.36 \pm 0.05 P>0.20$, all comparisons. Exposure to hyperoxia decreased the SOD activity to $0.32 \pm 0.05 \mathrm{U} / \mathrm{mg}$ wet wt $(88.8 \%$ of control values), and exposure to paraquat decreased the activity to $0.28 \pm .05 \mathrm{U} / \mathrm{mg}$ wet wt $(77.4 \%$ of control values) ( $P>0.1$, both comparisons). Thus catalase activity appears more labile than SOD activity in response to lung cell oxidant injury.

Evaluation of oxidant injury to human lung explants. Human lung parenchymal cells were susceptible to oxidant injury with an injury profile more similar to the rat than the rabbit (Fig. 10). Both paraquat and hyperoxia directly injured human lung cells, and their simultaneous use resulted in cytotoxicity clearly above the effect of either agent alone $(P<0.01$, both comparisons). Catalase protected human lung cells from each type of oxidant injury $(P<0.05$, all comparisons), and $\alpha$-tocopherol significantly reduced the injury induced by hyperoxia as well as the combined use of paraquat and hyperoxia $(P<0.05$, both comparisons) (Table I). Whereas ascorbate and superoxide dismutase did not significantly reduce the human

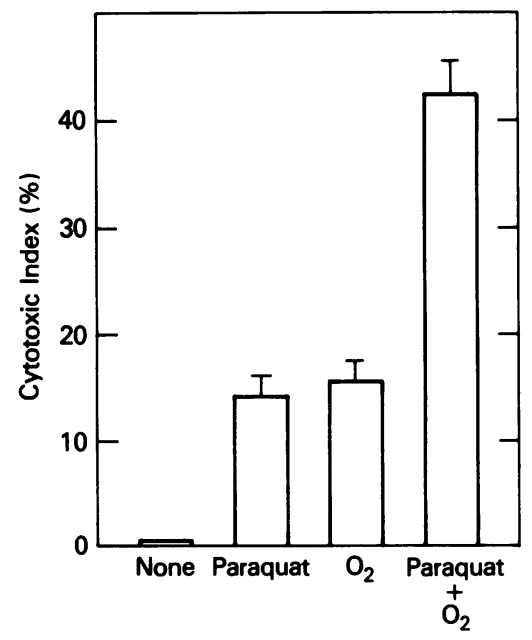

Figure 10 Direct oxidant injury to human lung parenchymal cells by paraquat, hyperoxia, and the combination of paraquat and hyperoxia. The ${ }^{51} \mathrm{Cr}$-labeled human lung explants were incubated with paraquat $(1 \mathrm{mM})$ and/or hyperoxia $\left(95 \% \mathrm{O}_{2}\right)$ for $18 \mathrm{~h}$. Whereas both paraquat and hyperoxia alone induced direct parenchymal cell injury, their combined use accelerated the injury well beyond that induced by either agent alone $(P<0.01$, both comparisons). Data represent mean $\pm S E M$.
TABLE I

Protection Afforded to Human Parenchymal Lung Cells by Antioxidants from the Direct Cytotoxic Effects of Paraquat andlor Hyperoxia

\begin{tabular}{cc}
\hline Condition & Cytotoxic index \\
& $\%$ \\
Paraquat & $14.3 \pm 2.0 *$ \\
+ SOD $\$$ & $11.6 \pm 1.6$ \\
+ CAT & $8.2 \pm 1.1 \S$ \\
+ ASC & $11.3 \pm 1.3$ \\
$+\alpha$ TOC & $9.2 \pm 1.5$ \\
O $_{2}$ & $15.8 \pm 1.7$ \\
+ SOD & $13.9 \pm 1.4$ \\
+ CAT & $9.5 \pm 1.4 \S$ \\
+ ASC & $12.8 \pm 2.1$ \\
$+\alpha$ TOC & $9.0 \pm 1.3 \S$ \\
& \\
Paraquat $+\mathrm{O}_{2}$ & $42.3 \pm 3.5$ \\
+ SOD & $31.4 \pm 3.0 \S$ \\
+ CAT & $18.8 \pm 1.711$ \\
+ ASC & $31.5 \pm 3.4 \S$ \\
+ + $\alpha$ TOC & $19.7 \pm 2.311$
\end{tabular}

* SOD, superoxide dismutase, $300 \mathrm{U} / \mathrm{ml}$; CAT, catalase, 1100 $\mathrm{U} / \mathrm{ml}$; ASC, ascorbate, $50 \mu \mathrm{g} / \mathrm{ml}$; $\alpha \mathrm{TOC}, \alpha$-tocopherol, $10 \mu \mathrm{g} / \mathrm{ml}$.

$\ddagger$ Data represent mean \pm SEM.

$\S P<0.05$, compared with test oxidant above.

" $P<0.01$, compared with test oxidant above.

lung cell injury induced by either paraquat or hyperoxia alone, they did partially protect the lung cells from the accelerated cytotoxicity induced by the combined effect of paraquat and hyperoxia $(P<0.05$, both comparisons) (Table I). Thus, either paraquat or hyperoxia could directly injure human lung parenchymal cells, their simultaneous use could markedly accelerate this cytotoxicity, and several oxygen radical inhibitors, especially catalase and $\alpha$-tocopherol, were capable of reducing the injury.

\section{DISCUSSION}

Oxygen toxicity and paraquat ingestion represent two clinical examples where cytotoxicity is thought to be mediated by oxidant mechanisms in which the lung serves as the primary target organ. This study demonstrates that both hyperoxia and paraquat can directly injure lung parenchymal cells and that this injury can be at least partially ablated by inhibitors of oxygen radical generation.

Mechanisms of lung cell injury induced by paraquat and oxygen. The ${ }^{51} \mathrm{Cr}$ lung explant system was developed to quantitatively evaluate whether lung parenchymal cells comprising the alveolar structures could be directly injured by exposure to oxidants 
known to cause human lung disease. The data suggests that both hyperoxia-induced and paraquat-induced lung cell injury can occur in an environment where recruitment of blood-borne inflammatory cells is not possible. This concept is consistent with studies demonstrating that hyperoxia can directly injure cultured alveolar macrophages (16-17) and lung L2 cells (18). Because polymorphonuclear leukocytes are not present in normal lung parenchyma (19-20), such as the explants used in this study, there is no potential role for polymorphonuclear leukocytes inducing any of the lung cell injury in these experiments. The alveolar macrophage, however, is present in normal lung tissue, is a potential effector cell of tissue damage, and is capable of generating oxygen radicals (19-21). It is possible that the alveolar macrophage could mediate the cytotoxicity observed in this lung explant system, but this is unlikely for several reasons: $(a)$ In a 2-mg explant of lung, there are $\sim 2-3 \times 10^{4}$ macrophages compared with $\sim 4-6 \times 10^{5}$ lung parenchymal cells [cell number data based on DNA determinations of explants (data not shown) together with morphometric data (22-23)]. This would result in an effector/ target cell ratio of $<1: 20$, far below that usually required for macrophage-mediated cytotoxicity, as measured by ${ }^{51} \mathrm{Cr}$ release from very susceptible target cells (19-20). (b) Under the conditions used for this study, the macrophage would not be able to increase this effector/target ratio because it would not be able to replicate $>1 \%$ of its population $(20,24,25)$. (3) In addition, there is evidence that in vitro oxidant exposure impairs alveolar macrophage function rather than stimulating it (16-17). Thus, lung parenchymal cells can be injured by oxidants, such as paraquat or hyperoxia, without the need to implicate a secondary mechanism mediated by inflammatory cells.

Although it is clear that $\mathrm{O}_{2}$ radicals can injure a variety of target cells (26-30), the specific mechanism by which they do so is unknown. $\mathrm{O}_{2}$ radicals are able to alter DNA (31), depolymerize polysaccharides (32) deplete $\operatorname{NADPH}^{2}(6,33)$, facilitate the autooxidation of amines (34) and thiols (35), and cause lipid peroxidation (36-37). In each species tested, catalase and $\alpha$-tocopherol provided the best protection for lung parenchymal cells from oxidant injury and this may provide a clue to the site of cellular injury. Catalase is a large macromolecule $(232,000$ daltons) that catalyzes $\mathrm{H}_{2} \mathrm{O}_{2}$ to $\mathrm{H}_{2} \mathrm{O}$ and $\mathrm{O}_{2}$. Because of its size, it is likely that catalase remains largely extracellular in this explant system. Because catalase effectively reduces the cytotoxic effect of both paraquat and hyperoxia, this implies that $\mathrm{O}_{2}$ radicals exert their effect near the cell surface where catalase may have access. Cell membranes are rich in lipids containing reactive unsaturated double bonds (30-39), therefore catalase might exert its protective effect by reducing $\mathrm{O}_{2}$ radical generation in the vicinity of the cell membrane. Alpha-tocopherol, the other oxygen radical inhibitor that was consistently protective against hyperoxia and paraquat, is a lipid soluble vitamin that accepts electrons from unstable radical species (37-38). Being lipid soluble, $\alpha$-tocopherol might have access to the lipid layer of the cell membrane, protect unsaturated double bonds within cell membrane lipids, and thus help to maintain the integrity of the cell $(38,40)$. Consequently, because one agent that is effective in reducing the oxidant injury is primarily extracellular (catalase) and another effective agent presumably can be intracellular ( $\alpha$-tocopherol), it suggests that the critical cytotoxic lesion these agents are reducing resides at the extracellular-intracellular interface, i.e., the cell membrane.

Additionally, the marked protective effects of catalase in both paraquat and hyperoxia-induced lung injury implies an important role for $\mathrm{H}_{2} \mathrm{O}_{2}$ in the genesis of lung cell injury. $\mathrm{H}_{2} \mathrm{O}_{2}$ can be cytotoxic by itself or can react with $\mathrm{O}_{2}^{-}$(in the presence of $\mathrm{Fe}^{+++}$) via the Haber-Weiss reaction to generate the highly toxic hydroxyl radical (41). The reason for the efficacy of catalase in preventing lung cell injury in this explant system is not clear, although it is likely that it either directly reduces the toxic substance $\left(\mathrm{H}_{2} \mathrm{O}_{2}\right)$, or it interrupts the propagation of even more toxic radical species.

Effect of paraquat and hyperoxia on endogenous antioxidant levels in lung explants. The response of lung parenchymal cells to sublethal concentrations of various oxidants can result in an increase in its endogenous antioxidant enzymes (42-45). However, the response of lung parenchymal cells to the cytotoxic concentrations of paraquat and $95 \% \mathrm{O}_{2}$ resulted in a significant decrease in the endogenous levels of catalase, but not superoxide dismutase. The inability of the oxidant-injured lung cells to increase or even maintain their antioxidant reserve is likely related to the overwhelming injury induced by the test oxidants. The preferential loss of catalase activity compared with superoxide dismutase activity is probably due to the ease in which catalase can be inactivated, even stored as a purified protein at $-20^{\circ} \mathrm{C}(46)$. It is possible that some of the marked protective effects of exogenously added catalase to the oxidant-injured explants is related to the replacement of this lost enzymatic function, although as noted earlier, the exogenous enzymes likely remain entirely extracellular. The maintenance of endogenous superoxide dismutase levels in the face of overwhelming oxidant injury may also suggest a role for this enzyme in the protective response of lung cells to injury by oxidant mechanisms.

Combined effects of paraquat and oxygen on lung cell injury. In vivo studies have demonstrated that the pulmonary injury induced by paraquat is exacer- 
bated by hyperoxia (47). The present in vitro study shows that this hyperoxia exacerbation of paraquatinduced cytotoxicity does not require blood-borne inflammatory cells to be manifest. In addition, the acceleration of lung cell injury in the presence of both paraquat and hyperoxia suggests that oxidants acting together may result in synergistic cytotoxicity. However, the paraquat dose-response curves (Fig. 9) can also be interpreted to demonstrate that once an "oxidant burden" to the cell reaches a certain threshold, cytotoxicity quickly accelerates. Thus, addition of hyperoxia to this system may simply increase the oxidant burden such that this threshold is more quickly reached. Rather than being synergistic, oxygen may be acting to increase the oxidant burden (as would increasing the paraquat concentration), and thus shift the cytotoxicity to the accelerated portion of the doseresponse curve.

Relative vulnerability of lung parenchymal cells of various species to oxidant injury. There are known species differences in the in vivo response of experimental animals to various oxidants (48-49). Species differences were also found in this in vitro study. Consistently, rabbit lung explants were more resistant to oxidant injury than were rat or human lung explants. Thus, the recognized resistance of the rabbit to oxidant injury in vivo $(48-49)$ is reflected by resistance at the level of the lung cell. This observation suggests that the in vivo resistance of rabbit lung to oxidant injury is not due to extrapulmonary factors, but rather to an inherent resistance of the lung parenchymal cells. The basis for this resistance is unknown, but could be due to species differences in the structure of the lung cell (e.g., susceptibility of unsaturated lipids in cell membranes to attack by oxygen radicals) or could be due to species differences in the endogenous cellular reserves of oxygen radical inhibitors. The latter concept is supported by the association of successful adaptation of the rat to hyperoxic conditions with an increase in its endogenous antioxidant enzymes (42-45).

Sensitivity of human lung to oxidant injury. Human lung explants obtained from surgical biopsy specimens provided the opportunity to study the effects of oxidant exposure on human lung parenchymal cells. The human lung cells were directly injured by exposure to paraquat and/or hyperoxia, and as demonstrated for rat and rabbit lung cells, were most consistently protected by catalase and $\alpha$-tocopherol. Attempts to extrapolate from a human lung explant system to the intact human condition is tempting, but fraught with problems. Certainly, the impressive blockade of oxidant injury by catalase and $\alpha$-tocopherol lends credence to their potential therapeutic role in situations of high oxidant exposure. However, catalase would likely be unable to obtain access to the lung cell surface in the manner made possible by an in vitro lung explant system. In addition, attempts to achieve a therapeutic concentration of catalase derived from species other than humans would likely also lead to problems with antigenicity. Alpha-tocopherol, on the other hand, has a relatively low molecular weight (531) and is lipid soluble and thus would likely have relatively free access to the environment of the lung parenchymal cell. Alpha-tocopherol also has a broad range of safety (50-51) and preliminary studies suggest a possible benefit in the treatment of oxygen-induced lung and eye injury in the newborn (52-54). Its protective role in the adult patient receiving a highly inspired oxygen concentration has not been demonstrated, but its therapeutic potential remains an interesting possibility.

The lung explant as a model system for evaluating acute lung injury. The ${ }^{51} \mathrm{Cr}$-labeled lung explant with its diverse cell population is especially useful for the investigation of acute lung injury for several reasons: (a) it permits the evaluation of direct injury to lung parenchymal cells in a controlled local environment where nonlung variables have been eliminated; $(b)$ it is quantitative; and $(c)$ it uses as the target of injury the lung parenchyma containing the full complement of lung cells in their normal ratios and spatial positions within the alveolar structures. The in vitro ${ }^{51} \mathrm{Cr}$ lung explant system approximates the in vivo condition, and may be useful in the investigation of other types of acute lung injury, including adverse drug reactions, acute radiation pneumonitis, and toxic gas exposure. Any or all of these agents may cause a direct injury, elicit a secondary indirect response through inflammatory cells, or may cause lung damage through a combination of these processes. This study has presented a model for direct injury to lung parenchymal cells and a framework in which lung cell injury may be further investigated.

\section{REFERENCES}

1. Halliwell, B. 1978. Biochemical mechanism accounting for the toxic action of oxygen of living organisms: the key role of superoxide dismutase. Cell. Biol. Int. Rep. 2: 113-128.

2. Clark, J. M., and C. J. Lambertsen. 1971. Pulmonary oxygen toxicity: a review. Pharmacol. Rev. 23: 37-133.

3. Fridovich, I. 1978. The biology of oxygen radicals. Science (Wash., D. C.). 201: 875-880.

4. McCord, J. M., and I. Fridovich. 1978. The biology and pathology of oxygen radicals. Ann. Intern. Med. 89: 122-127.

5. Roehm, J. N., J. G. Hadley, and D. M. Menzel. 1971. Antioxidants vs. lung disease. Arch. Intern. Med. 128: 88-93.

6. Smith, L. L., M. S. Rose, and I. Wyatt. 1978. The pathology 
and biochemistry of paraquat. C.I.B.A. Found. Symp. 65: 321-341.

7. Mustafa, M. G., and D. F. Tierney. 1978. Biochemical and metabolic changes in the lung with oxygen, ozone, and nitrogen dioxide toxicity. Am. Rev. Respir. Dis. 118: 1061-1090.

8. Guerro, R. R., D. E. Rounds, and J. Booker. 1977. An improved organ culture method for adult mammalian lung. In Vitro (Rockville). 13: 517-524.

9. Lillie, R. D. 1963. Histopathologic Technic and Practical Histochemistry. McGraw-Hill Book Company, New York, 647-651.

10. Bradley, K. H., S. D. McConnell, and R. G. Crystal. 1974. Lung collagen composition and synthesis. J. Biol. Chem. 249: 2674-2683.

11. McCord, J. M., and I. Fridovich. 1969. Superoxide dismutase: an enzymatic function for erythrocuprein hemocuprein. J. Biol. Chem. 244: 6049-6055.

12. Wroblewski, F., and J. S. LaDue. 1955. Lactic dehydrogenase activity in blood. Proc. Soc. Exp. Biol. Med. 90: 210-213.

13. Beers, R. F., and I. W. Sizer. 1952. A spectrophotometric method for measuring the breakdown of hydrogen peroxide by catalase. J. Biol. Chem. 195: 133-140.

14. Brunner, K. T., H. D. Engers, and J-C. Cerottini. 1976. The ${ }^{51} \mathrm{Cr}$ release assay as used for the quantitative measurement of cell-mediated cytolysis in vitro. In In Vitro Methods in Cell-Mediated and Tumor Immunity. B. R. Bloom and J. R. David, editors. Academic Press, Inc., New York, 423-428.

15. Bienkowski, R. S., M. J. Cowan, J. A. McDonald, and R. G. Crystal. 1978. Degradation of newly synthesized collagen. J. Biol. Chem. 253: 4356-4363.

16. Simon, L. M., S. G. Axline, and E. D. Robin. 1978. The effect of hyperoxia on phagocytosis and pinocytosis in isolated pulmonary macrophages. Lab. Invest. 39: 541-546.

17. Raffin, T. A., L. M. Simon, D. Braun, J. Theodore, and E. D. Robin. 1980. Impairment of phagocytosis by moderate hyperoxia (40 to 60 percent oxygen) in lung macrophages. Lab. Invest. 42: 622-626.

18. Raffin, T. A., W. Douglas, L. M. Simon, J. Theodore, and E. D. Robin. 1977. Effects of hyperoxia on ultrastructure and superoxide dismutase (SOD) activity in cultured type II pneumocytes (Type II-P). Clin. Res. 25: 422A.

19. Hunninghake, G. W., and A. S. Fauci. 1976. Immunological reactivity of the lung. II. Cytotoxic effector function of pulmonary mononuclear cell subpopulations. Cell. Immunol. 26: 98-104.

20. Hunninghake, G. W., J. E. Gadek, S. V. Szapiel, I. J. Strumpf, O. Kawanami, V. J. Ferrans, B. A. Keogh, and R. G. Crystal. 1980. The human alveolar macrophage. In Methods in Cell Biology. C. Harris, B. F. Trump, and G. D. Stoner, editors. Academic Press, New York. 95-112.

21. Hoidal, J. R., G. D. Beall, and J. E. Repine. 1979. Production of hydroxyl radicals by human alveolar macrophages. Infect. Immun. 26: 1088-1092.

22. Crapo, J. D., B. E. Barry, H. A. Foscue, and J. Shelburne. 1980. Structural and biochemical changes in rat lungs occurring during exposures to lethal and adaptive doses of oxygen. Am. Rev. Respir. Dis. 122: 123-143.

23. Barry, B. E., J. D. Crapo, P. Gehr, M. Bachofen, and E. R. Weibel. 1979. Population characteristics of the cells in normal human lung. Am. Rev. Respir. Dis. 119: 287 (Abstr.).

24. Golde, D. W., T. N. Finley, and M. J. Cline. 1974. The pulmonary macrophage in acute leukemia. New Engl. J. Med. 290: 875-878.

25. Golde, D. W., L. A. Byers, and T. N. Finley. 1974. Proliferative capacity of human alveolar macrophage. Nature (Lond.). 247: 373-375.

26. Babior, B. M., J. T. Curnutte, and R. S. Kipnes. 1975. Biological defense mechanisms. Evidence for the participation of superoxide in bacterial killing by xanthine oxidase. J. Lab. Clin. Med. 85: 235-244.

27. Hassan, H. M., and I. Fridovich. 1979. Paraquat and Escherichia coli. Mechanism of production of extracellular superoxide radical. J. Biol. Chem. 254: 1084610852.

28. Kellogg, E. W. III, and I. Fridovich. 1977. Liposome oxidation and erythrocyte lysis by enzymically generated superoxide and hydrogen peroxide. J. Biol. Chem. 252: 6721-6728.

29. Murray, H. W., and Z. A. Cohn. 1979. Macrophage oxygen-dependent antimicrobial activity. I. Susceptibility of toxoplasma gondii to oxygen intermediates. J. Exp. Med. 150: 938-949.

30. Sacks, T., C. F. Moldow, P. R. Craddock, T. K. Bowers, and H. S. Jacobs. 1978. Oxygen radicals mediate endothelial cell damage by complement-stimulated granulocytes. J. Clin. Invest. 78: 1161-1167.

31. White, H. L., and J. R. White. 1966. Interaction of streptonigrin with DNA in vitro. Biochim. Biophys. Acta. 123: 648-651.

32. Harris, M. J., A. Herp, and W. Pigman. 1971. Depolymerization of polysaccharides through the generation of free radicals at a platinum surface: a novel procedure for the controlled production of free-radical oxidations. Arch. Biochem. Biophys. 142: 615-622.

33. Steffen, C., and K. J. Netter. 1979. On the mechanism of paraquat action on microsomal oxygen reduction and its relation to lipid peroxidation. Toxicol. Appl. Pharmacol. 47: 593-602.

34. Heikkila, R. E., and G. Cohen. 1973. 6-Hydroxydopamine: evidence for superoxide radical as an oxidative intermediate. Science (Wash., D. C.). 181: 456-457.

35. Misra, H. P. 1974. Generation of superoxide free radical during the autooxidation of thiols. J. Biol. Chem. 249: 2151-2155.

36. Bus, J. S., S. D. Aust, and J. E. Gibson. 1974. Superoxide and singlet oxygen-catalyzed lipid peroxidation as a possible mechanism for paraquat (methyl viologen) toxicity. Biochem. Biophys. Res. Commun. 58: 749-755.

37. Tappel, A. L. 1972. Vitamin $E$ and free radical peroxidation of lipids. Ann. N. Y. Acad. Sci. 203: 12-28.

38. Lucy, J. A. 1972. Functional and structural aspects of biological membranes: a suggested structural role for vitamin $E$ in the control of membrane permeability and stability. Ann. N. Y. Acad. Sci. 203: 4-11.

39. Feeney, L., and E. R. Berman. 1976. Oxygen toxicity: membrane damage by free radicals. Invest. Ophthamal. 15: 789-792.

40. Menzel, D. B., J. N. Roehm, and S. D. Lee. 1972. Vitamin E: the biological and environmental antioxidant. J. Agric. Food Chem. 20: 481-486.

41. McCord, J. M., and E. D. Day. 1978. Superoxide-dependent production of hydroxyl radical catalyzed by ironEDTA complexes. FEBS (Fed. Eur. Biochem. Soc.) Lett. 86: $139-142$.

42. Kimball, R. E., K. Reddy, T. H. Pierce, L. W. Schwartz, M. G. Mustafa, and C. E. Cross. 1976. Oxygen toxicity: 
augmentation of antioxidant defense mechanisms in rat lung. Am. J. Physiol. 230: 1425-1431.

43. Crapo, J. D., and D. F. Tierney. 1974. Superoxide dismutase and pulmonary oxygen toxicity. Am.J. Physiol. 226: 1401-1407.

44. Crapo, J. D., K. Sjostrom, and R. T. Drew. 1978. Tolerance and crosstolerance using $\mathrm{NO}_{2}$ and $\mathrm{O}_{2}$. I. Toxicology and biochemistry. J. Appl. Physiol. Respir. Environ. Exercise Physiol. 44: 364-369.

45. Frank, L., J. R. Bucher, and R. J. Roberts. 1978. Oxygen toxicity in neonatal and adult animals of various species. J. Appl. Physiol. 45: 699-704.

46. Aebi, H. 1974. Catalase. In Methods of Enzymatic Analysis. H. V. Bergmeyer, editor. Academic Press, New York, 673-684.

47. Fisher, H. K., J. A. Clements, and R. R. Wright. 1973. Enhancement of oxygen toxicity by the herbicide paraquat. Am. Rev. Respir. Dis. 107: 246-252.

48. Butler II, C., and J. Kleinerman. 1971. Paraquat in the rabbit. Brit. J. Ind. Med. 28: 67-71.
49. Clark, D. G., T. F. McElligott, and E. W. Hurst. 1966. The toxicity of paraquat. Brit. J. Ind. Med. 23: 126-132.

50. Horwitt, M. K. 1980. Therapeutic uses of vitamin $E$ in medicine. Nutr. Rev. 38: 105-113.

51. Farrell, P. M., and J. G. Bieri. 1975. Megavitamin E supplementation in man. Am. J. Clin. Nutr. 28: 13811386.

52. Johnson, L., D. Schaffer, and T. R. Boggs, Jr. 1974. The premature infant, vitamin $\mathrm{E}$ deficiency and retrolental fibroplasia. Am. J. Clin. Nutr. 27: 1158-1173.

53. Ehrenkranz, R. A., B. W. Bonta, R. C. Ablow, and J. B. Warshaw. 1978. Amelioration of bronchopulmonary dysplasia after vitamin E administration. New Engl. J. Med. 299: 564-569.

54. Ehrenkranz, R. A., R. C. Ablow, and J. B. Warshaw. 1979. Prevention of bronchopulmonary dysplasia with vitamin $E$ administration during the acute stages of respiratory distress syndrome. J. Pediatr. 95: 873-878. 